\title{
Social Context of Accomplishing Welfare Tasks in Poland in 1980s and Nowadays
}

Arkadiusz Urbanek / e-mail: pedagog@pedagogika.uni.wroc.pl Institut of Pedagogy, University of Wrocław, Poland

Urbanek, A. (2013). Social Context of Accomplishing Welfare Tasks in Poland in 1980s and Nowadays. Czech-Polish Historical and Pedagogical Journal, 5/2, 33-43. doi: 10.2478/cphpj-2013-0012

The article tackles theoretical and empiric issues. On one hand, it makes an attempt to present the evolution of the social welfare services in Poland from 1945 to the 1990s. On the other, on the basis of such historic process, it tackles the issue of the social context in which were, and still are accomplished tasks of the social welfare. For this purpose, the results of interviews with social welfare workers have been presented, referring to those working in such institutions in the 1980s, and contemporarily. The aim of the research was to capture the changes perceived by the social workers as far as the beneficiary groups of social welfare services are concerned in these two, different time realities. The outcomes of the research point at issues crucial for social pedagogy, focusing on different attitudes towards social work and various exceptions of the beneficiaries.

Key words: Social welfare; Social work; Social worker

\section{Introduction}

The period at the turn of 1980s and 1990s became for many societies a turning point creating new life reality. In Poland, similarly as in many socialistic block countries of that time, transformation processes took place particularly dynamical, affecting political, legal, economic as well as social aspect of the everyday life reality. In such circumstances, the system of social welfare was also subject to changes, both in its institutional as well as ideological dimension.

Nevertheless, from the perspective of the theory of the pedagogy of social welfare and social pedagogy, the social context in which the system of assistance works is particularly important. Therefore, the main goal of this paper is to outline the social issues that constitute the background for social work. As early as in 1920s, Helena Radlińska emphasized the significance of social and environmental conditions of social activities ${ }^{1}$, thanks to which the social care reached beyond individual situations, towards the social context. Such an idea became

Olubiński, A. (2004): Praca socjalna. Aspekty humanistyczne i pedagogiczne. Teoria i praktyka. Toruń, p. 19. 
the inspiration to search for information on specific features of a society, where the social welfare takes place, taking into account that not only the system of social welfare is subject to modification, but expectations of its participants also change. The aim of this paper is the attempt to perceive the social work from the perspective of changes within its recipients. Because of that, the empirical material refers to the outcome of the interviews with social care workers, that had been carrying out their duties in 1980s, and have been doing the same currently. Those are people, who not only have a lot of professional experience, but predominantly - they notice the process of changes in social groups that receive social welfare benefits. In both if the periods the social care duties were carried out along with direct social work, nevertheless the nature of the system and institutions, as well as point of view on the helping styles, were also subject to change, therefore it is also worth to pose questions on changes that occurred within the groups social care was addressed to.

The basic issue of the reflection is the attempt to answer the questions:

How did the system of the institution of welfare evolved in Poland with regards to the changing circumstances of social life?

How do the social workers interpret the social context of accomplishing social welfare?

\section{The outline of the evolution of the institutions accomplishing the social care and welfare tasks}

In the period after 1945, Poland - as many other countries- struggled with the effects of war. Apart from the issues of war damages, the social problems were significant too, as for the poverty and people's migration. In response to the everyday existential social needs, in the years 1945-1947, support - actually the social care - performed rescuing tasks.

According to Waldemar A. Góra, undertaking such activities was a natural consequence of the postwar social situation, as families began to search for their members separated by the conflict, with prisoners of German concentration camps returning home, but also with reference to numerous repatriates whose property had been taken away and with very basic possession they had to adopt to life in the new places ${ }^{2}$. Thousands of people expected to receive a tangible help in finding a shelter or even

2 GÓRA, W. A.: Tradycje opieki i pomocy społecznej w Polsce. Praca Socjalna, nr 2/1989, pp. 32-33. 
food, as they were often sick and traumatized by the war and its atrocities.

The Ministry of Labour, Social Care and Health was established in 1945 with its local branches, dealing with accomplishment of social care tasks. It is worth to emphasize the term "social care" used within its notion, as it reflected the scale of the needs of that time. Focusing on the social problems, it was crucial to set up Central Committee of Social Welfare, which was developed on various local and administrative levels. The first framework of these institutions referred to the activities of the community workers, with the primary Committee tasks to: organize and support social welfare units, set up people's soup kitchen, provide meals for the undernourished, help the refugees and repatriates, consolidate the actions of social care institutions. The costs of operating of these institutions were covered by governmental and local government budget subventions, as well as public donations ${ }^{3}$. Wanda Pawłowska, describing the reconstruction of social care in the postwar Warsaw, emphasized the quick pace and great efforts to rebuild the institutions of social welfare as well. The proof of such is the periodical "Social Service" issued in 1946, founded by Polish Institute of Social Services - reactivated in 1945 and engaged in scientific activities. The reconstruction movement focused also on the teaching process, as Helena Radlińska began in 1945 her activities at University of Łódź, establishing a department of social pedagogy 4 . In 1945 there were 18 local points of Polish Red Cross operating, carrying out tasks focusing on nourishing children at schools and providing care for those in orphanages.

In the years 1947-1953 a reorganization stage took place within the existing social welfare institutions, at the same time launching the systematization of social activities. Nevertheless, the period of reorganization did not cause a breakthrough effects. The regulations from the Act on Social Care from 1923 expired, as the new Act on the local bodies of united state authority established few departments, among which the care taking and support activities were divided, hence, the education, health and the justice department all undertaking various tasks of supporting and protecting children and families ${ }^{5}$. Such changes were reflected in the act handing over the range of duties from the Ministry of Education to the Ministry of Labour and Social Welfare from $7^{\text {th }}$

3 DĄBROWSKI, L.: Opieka społeczna w pierwszych latach powojennych na Pomorzu Środkowym. Praca Socjalna, nr 1/1988, pp. 25-27.

4 PAWŁOWSKA, W.: op. cit., p. 73.

5 GÓRA, W. A.:, op. cit., p. 32. 
April 19496. The same year the committees of social care had been closed down and replaced by the Department of Health and Social Welfare?.

The wide-spread action of nationalizing care institutions for children in 1952 revealed the political intentions and the true intentions of the propaganda, as the already-existing institutions lost their right to exist and became subject to the jurisdiction of state authority ${ }^{8}$. A new way of interpreting social welfare was signaled - i.e. to nationalize and centralize, what - in the context of contemporary ideologies - turned out to be unfortunate. Such direction of changes was confirmed by the constitution of Polish People's Republic dated 22nd July 1950, where the privilege to use social care and health protection was formulated as a civic right. It is also worth to stress the change in terminology, as the so far "social care" became in its meaning and sense a "social welfare". Wiesław Theiss rightly indicated, that after 1945 the rich traditions of support and social care in pre-war Poland had been forsaken, as seen in the negation of the achievements of the organizations and institutions up till then?.

The third stage of the development in the system of social welfare took place between the years 1953-1970, where unfortunately so far reached achievements had become dominated by propaganda and political objectives, however the promoted policy of socialistic success and dynamic economic growth may have not deliberately stopped the growth of already operating social infrastructure ${ }^{10}$. The role of the propaganda of socialism success turned out to be more important than any other real social needs, and it is rather hard to agree that the excluded groups had been eliminated. Still, the socialistic propaganda presented the existing situation as a success in fighting with poverty, as it seemed obvious that the compulsion of employment would obviously eliminate the poverty. Therefore, if there was no one without work in People's Poland, there was no one to support, so there was very small interest of the authorities in developing the system of social welfare ${ }^{11}$.

Only few years after, faith in such limitless successes fainted and failed, whereas the social problems remained. As a consequence of

$6 \quad$ Ustawa o opiece społecznej. 16 sierpnia 1923 r., Dz. U. R. P. nr 92, poz. 726, with later amendments.

7 DĄBROWSKI, L.: op. cit., p. 29.

8 DĄBROWSKI, L.: op. cit., p. 32.

9 GŁADKOWSKA, M.: Opieka społeczna w Warszawie 1923-1947. Warszawa 1995, p. 7.

10 GÓRA, W. A.: op. cit., pp. 32-33.

11 GÓRA, W. A.: op. cit., pp. 32-33. 
given tasks and social expectations, the government passed a bill in 1958 establishing the institutions of Social Care workers, both at local and county levels ${ }^{12}$. The range of their duties was initially regulated by the government order of the Ministry of Labour and Social Welfare concerning the range and mode of the activities of social care workers dated 1957, with later amendments from $1964 .{ }^{13}$ It is worth to emphasize the significance of the change also in the context of accomplishing the social care, as previously it had been perceived as a work not requiring specific competences and activities, perceiving it a passive job. "There is an opinion held that social care work is mainly of administrative character (...) more manual than intellectual, not a work in field, neither of offensive character, more a passive waiting for the demanding patient, that has privileges granted by the law"14. Introducing the social care workers to the system of support implied a change from passive to active manner of work, as the social work was to be performed mainly in the field, aiming at finding those in need, recognizing the environmental needs too 15 .

In the 1960, the government established Ministry of Health and Social Welfare, whilst concurrently some changes in the expectations of those directly carrying out the social tasks took place. Until that time, the key role had been played by community workers, engaged in the idea of helping. Such an idea may rise doubts as for the promoted enthusiasm that the socialistic social care abandoned philanthropy. After all, social activity, i.e. offering own labour, concerns the personal readiness for activity for the sake of the needy. Nevertheless, it was equally difficult to refer to the legally binding standards of the social care service, that in fact did not exist. However, an important step ahead took place when the Department of Social Welfare and the Ministry of Labour and Social Welfare, began to publish an expertise periodical "Bulletin of the Social Care Worker", with its primal aim to educate the community workers, who "lacked no heart nor good will, but knowledge and experience" 16.

The 1970s defined a period when a double stream of building social system was reported. On one hand, the standards were indicated by the

12 OLESZCZYŃNSKA, A.: Pomoc społeczna w roku jubileuszu. Opiekun Społeczny, nr 2/1979, p. 56.

13 Rozporządzenie MPiOS o zakresie i trybie działania opiekunów społecznych. MP 1959 r., Nr 93, poz. 496, MP 1964 r., nr 62, poz. 287.

14 ADAMOWICZ, K.: O konsekwencjach praktycznych niejednoznacznego rozumienia terminu „praca socjalna”. Praca Socjalna, nr 1/1987, pp. 47-50.

15 GÓRA, W. A.: op. cit., p. 33.

16 KACZEWSKI, M.: Od Biuletynu opiekuna Społecznego do Pracy Socjalnej. Praca Socjalna, nr 1/1986, pp. 4-6. 
budget guarantees (not by philanthropy), national organizations and system of the social law procedures, but on the other - there was lack of explicit standards of exercising these rights and activities. In the years 1973-1974 some serious problems arose while accomplishing the social tasks by the social care workers as "at that time there were 66000 social workers, often elderly people with elementary education, not always well classifying and recognizing the needs. They expressed a lot of good will and eagerness (...) but did not subordinate as they acted voluntarily as a charity and often operated not quick and efficient enough" 17 . Therefore, the priority was to educate the staff professionally prepared to undertake social tasks. The educational movement had been intensified in the 1960s, however it is worth to mention that those were not first such schools in Poland, as in the years 1925-1939 there was a College of Social and Educational Work at the Free Polish University, that managed the trainings of the staff accomplishing social tasks ${ }^{18}$. Until 1939 it had educated around 500 graduates, operating later in conspiracy until $1944^{19}$. In that period it was crucial to develop network of support institutions and increase their potential of knowledge and competences. The experiences of Olsztyn can be recalled, as in 1969 there was a Regional Centre of the Social Workers operating, with its main goals to increase the professionalism of the local activities of social care workers 20 .

Establishing the Regional Centers of Social Care Workers coexisted with the already operating Health and Social Welfare Departments, working within the voivodship local authorities.

Two group of people accomplishing social support tasks emerged. On one side those were the traditional filed working community staff subordinated to the Health and Social Care Department. Social workers as professionally trained staff replaced the already working social care workers, initially cooperating with them, overtaking their duties subsequently. The result of such changes led to the establishment of network of organizational structures, as from 1969-1975 a network of Voivodship Centers for Social Care Workers were developed, located at regional unit of health care institutions, whereas at lower level they were included within the structure of the local health care centers. This new organization was set up in order to supervise the creation of the new tools

17 KAŹMIERCZAK, T.: O wojewódzkich ośrodkach opiekuna spotecznego raz jeszcze. Praca Socjalna, nr 1/1989, p. 39.

18 OLUBIŃSKI, A.: op. cit., pp. 17-19.

19 GŁADKOWSKA, M.: op. cit., p. 8.

20 KAŹMIERCZAK, T.: op. cit., p. 39. 
of social work profession: "...appropriate regulation for the activities the social care centers, as well as supervision and trainings were beyond the possibilities of the Health and Social Care Departments due to insufficient number of staff in the social care units, hence the necessity to establish regional section in the regional networks of specialist health care centers" 21 .

It is worth to emphasize that social care actions constituted a part of broadly understood health services, therefore social care workers were employed within the health care centers. The Health and Social Care Ministry directive dated $4^{\text {th }}$ July 1975 , established the Voivodship Centers of Social Care workers, which was a part of the development of the professional social care working staff, as recognized by the Decision $29 / 73$ of the presidium of the government 22 . The development and specialization of this profession led to setting up a state organization, and Polish Society of Social Care Workers was established in 1987 an it has been still operating.

In 1990s, the social welfare system changed dramatically, both as for new tasks, legal regulations as well as new organization was concerned. In 1990 a new Act on social welfare was established, with later amendments in 2004. The social welfare tasks were assigned to the newly organized (1987-2003) Ministry of Labour and Social Policy. It launched a new stage of social care evolution, accompanied with profound changes in the administrative organization of the entire country. After the national administrative reform, from 1999 the number of social support institutions increased, both at regional and local level. Decentralization processes followed, aiming at overtaking responsibility from social welfare by the local governments, that were subject to the social exclusion, hence - in natural consequence - the supporting environment23.

Social context of accomplishing tasks of social welfare

The outlined evolution of systematic solutions within the social policy, did not take place regardless of given social needs. Referring to various definitions of social welfare 24 , it is evident that the society (community) is

$21 \quad$ KAŹMIERCZAK, T.: op. cit., p. 39.

22 KAŹMIERCZAK, T.: op. cit., p. 46.

23 URBANEK, A.: Realizacja zadań pracownika socjalnego w praktyce. Legnica 2012, pp. 19-21.

24 National Association of Social Workers. Encyclopedia of Social Work 1971, vol. 2. 
a crucial part of its evolution, concerning people participating on both sides - those addressing and receiving social support 25 . The vision of changes occurring in the society is a part of evolution of the social welfare system itself, as its tasks are accomplished with direct correspondence to the expectation and needs of the recipients 26 . Searching for information on changes taking place in these groups, I conducted interviews with social care workers directly involved in the social work both in 1980s and currently. The interviewed group consisted of 5 people with significant professional experience in the social welfare system (from 27 to 32 years of working experience), i.e. those are persons whose knowledge allowed to recognize the general changes of the social background for accomplishment of the social welfare tasks.

It is worth to stress that the aim of the interviews was to capture the essential differences in the characteristics of social groups outlining the previous, and contemporary circumstances of the social activities. Therefore, the results of the interviews do not refer to the assessment of all the beneficiaries, but rather indicate the overall point of view. The conversations lasted 1-1,5 hours, concentrating on the personal features, life situation and the attitude of the beneficiaries towards the social welfare, with whom the social care workers worked in the 1980 s (.i.e. before the political transformation), and with those they are still working. It is worth to emphasize that the interviewed worked in various regions of the Dolny Śląsk and Opolskie voivodship, hence the given opinions are related to various environments.

Concentrating on common traits of the opinions, the similarity in assessment of the economic situation of the beneficiaries was striking, pointing different pricing relation in both of these periods. Despite it is of objective nature, it matters as for given attitudes of the recipients towards the social support. With regards to this aspect, in the five interviews, social workers claimed that in 1980s the received benefits made a real difference to the families, helping to overcome difficult situation, whereas contemporarily, it is rather handicapped or even impossible, as the benefits are consumed by direct costs of the family existence.

The general conclusions imply that in the 1980s, the social support was considered as a real help, whereas these days it is just an accompanying element of rather unchangeable life situation, and although the objective of social support is to help in overcoming difficult

25 STARĘGA-PIASEK, J.: Pojęcia pomocy społecznej. Praca Socjalna, nr 1/1986, pp. 4-8.

26 MARYNOWICZ-HETKA, E.: Istota i zakres służby społecznej. Praca Socjalna, nr 1/1986, p. 13. 
life situation, it is unfeasible nowadays. It is caused not by the unwillingness of the beneficiaries to improve their living conditions, but their deteriorating existential situation, as reflected in the interviewed opinions: "... low income, low benefits and high costs of living cause lack of efficiency", "the support we provide - sometimes reaching 1000 PLN a month - covers only such basic living needs as food or clothing (...) besides, our clients do not pay (...) real estate taxes, nor utilities bills (...) hence the debt is growing and problem is rising (...) Now people do not bother with growing vegetables, they must buy everything, they are used to another life style, they want to eat something different, have the comfort. No wonder they want to live a better life, but it makes the living more expensive". It is quite alarming, as the economic situations of families degrade beyond them, since high costs of living consume such proportion of the accessible resources, that it is hard to speak of the possibility to save up, as the expenses are related solely to the basic needs.

The social background of 1980s was assessed differently, as due to lack of unemployment, the number of those receiving social support was lowered, whereas the activities aimed at only given groups, such as the elderly, or large families. Still their needs were different: "I think it used to be more effective, as receiving benefits from such institutions really meant to receive some support that would equip the family with some goods (...) fuel or firewood". "People used to have more money and the costs of life were lower", "... we used to work with the elderly, (...) that did not ask for financial help and did not want to expose their poverty, simplymeeting the other person and talking about their problems mattered".

Another issue was the change in approach of the beneficiaries towards the social welfare, regarded in two dimensions: on one hand, it was the attitude towards the social welfare, and on the other - the readiness to act on own behalf for the sake of own situation. Taking into consideration the attitude, it used to be less demanding, what might have been caused by lack of knowledge, as they are opinions, that in the past the families did not know what kind of benefits they are entitled to, whereas now they are fully aware of it, even calculating, if they meet the criteria. The range of the increased knowledge evoked, according to the social care workers, another perception of the social support, i.e. not as a help, but something they are owed to.

The assessment of the engagement of the beneficiaries of social support revealed similar differences in case of the change of own life situation. It is reflected in the statements regarding engagement in the 
manifested social roles: "they use to be less demanding people, not taking that much for granted", "we had the field needs recognized, helpless people were not that common", "the level of education was similar, but they were more practical, mothers were resourceful, hardworking. Now the level of engagement changes, the social care tasks are accomplished somehow "nearby" the beneficiaries that manifest no willingness, certainty nor skills to overtake control and responsibility of own life: "the clients in most cases have basic education (...) and such fast termination of the educational process made them enter adult life as still immature children,(...) young mothers do not understand basic principles related to the child care, hence they must be supervised while applying for layettes, (...) they are kind of absent-minded, taking care of purely mundane issues".

\section{Summary}

The conclusions drawn from the empirical research indicate few aspects requiring further reflections and research, as they are of significant importance from the perspective of social pedagogy. The necessity to analyse the attitude of the social support beneficiaries is one of such cases. Generally, although the social services of 1980 s was directed at selected groups, nowadays it is addressed to wider and more diverse groups, including young people, who have undertaken the social role of parents and cannot efficiently meet the demands, as due to limited educational competences and little professional opportunities, they experience difficulties in providing for the children. The second group is constituted by those young people who consider social support as something they deserve, accepting the situation of living on the dole, being almost unwilling to search for independent sources of income. It is a crucial conclusion that the contemporary clients of social services manifest affiant determination to change their situation, not looking for own resources, but rather expecting to receive unemployment benefits considering it as source of income. And although it is an assessment of general nature, it reflects the observations of significant professional experience of the interviewed. Such situation is also a challenge for the social pedagogy, as it signalizes a precise problem, which is the acceptance of young people towards the role of social support recipient, and in comparison to 1980s, this tendency is growing.

Another, but equally important aspect, is the immaturity of parents while meeting the demands of the role they have taken. Social workers, 
while interviewed, frequently tackled this issue, pointing that it is very difficult to motivate one to overcome poverty if such person needs to be educated in the first place. They do not understand the complexity of their obligations towards own children and family, concentrating on arranging money for the basic needs. It is not irrational in its meaning, but the social workers draw attention to the lack of effort among young people to inspire and support change in their own family whatsoever. Current beneficiaries of social support are considered less hard-working, less engaged in the improvement of own situation, not thinking about their own and their children's future, but focusing on the daily life.

The common belief that social worker won't make their life change is also disturbing, as he/she is rather perceived as a clerk that allocates the money. This is another problem in understating the idea of social serve, since as a professional activity, its target is to inspire and support the changes in families, whereas the financial resources are only an aid and additional. Nowadays, it is quite the contrary as the families mainly expect financial support, not being ready and willing to change their life. Although it is a general conclusion, it is surprising how repeatable these opinions are, which means it is not a specificity of a given local community.

The aim of the reflection was to reveal various social contexts, through the analysis of the social welfare as a process of evolution in system and change occurring in given societies. There are constantly new issues and problems arising, that imply reformulation of the role of social care workers, that is basically somewhere between a clerk assessing the legitimacy of the client's claims, and on the other side - an animator of the process of overcoming difficult life situation. However, the appearing difficulties, also accented in the research results, shall not question the meaning of the social services, but rather point out a given outline of the contemporary reality. These are issues essential for the social pedagogy, particularly that, as Martin Davies claims, the social services shall resign from reaching to mechanical response to the needs and inconvenience 27 , as according to him, the social worker always acts accordingly to the belief that it is possible to combine the individual and social interest, so that his/her activities would equally serve the client and the country.

27 DAVIES, M.: The Essential Social Worker. A Guide to Positive Practice, 1985, p. 68. 